\title{
The Provision of Long-Term Credit and Firm Growth in Developing Countries
}

\author{
Jennifer Watson \\ Texas A \& M University, USA. \\ Email:jenni.watson@gmail.com
}

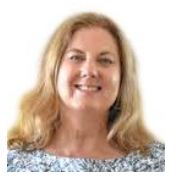

\begin{abstract}
This study evaluates the impact of the provision of long-term credit (LTC) on the growth of small and young firms in developing countries. The growth of firms is evaluated on the basis of employment growth and total sales. Credit provisions have also been collected from the short- and LTC extended to the private sector. This study uses data on firm levels from more than 19000 firms in 52 countries between 2006-2016. In order to avoid the endogeneity issues that usually occur in such studies, this study has implemented a cross-country model to evaluate the significance of total bank credit, both long- and short-term, on the growth of sales and employment. The econometric results indicate that the availability of short-term credit (STC) is more beneficial for the growth of the firms, i.e. STC was found to have a significant impact on employment growth and sales in small and young firms. Although positive, LTC seemed to have no significance in the growth of the small and young firms. This study suggests that the prime reason behind these results is the availability of long-term loans for small and young firms.
\end{abstract}

Keywords: Developing Countries; Bank Credit; Growth Development.

Citation | Jennifer Watson (2020). The Provision of Long-Term Credit and Firm Growth in Developing Countries. Asian Journal of Economics and Empirical Research, 7(2): 224-234. History:

Received: 3 July 2020

Revised: 5 August 2020

Accepted: 8 September 2020

Accepted: 8 September 2020

Licensed: This work is licensed under a Creative Commons

Attribution 3.0 License $(\mathrm{ccc})$

Publisher: Asian Online Journal Publishing Group
Funding: This study received no specific financial support

Competing Interests: The authors declare that they have no conflict of interests.

Transparency: The author confirms that the manuscript is an honest, accurate, and transparent account of the study was reported; that no vital features of the study have been omitted; and that any discrepancies from the study as planned have been explained.

Ethical: This study follows all ethical practices during writing.

\section{Contents}

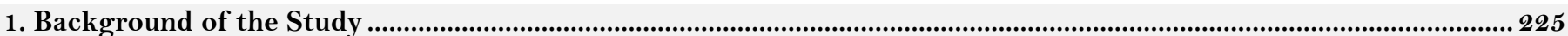

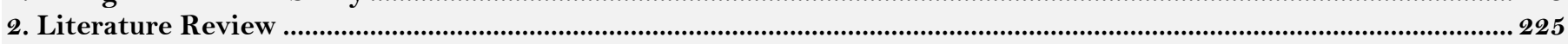

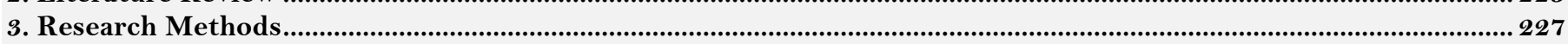

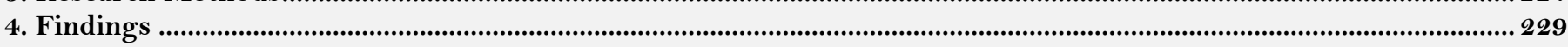

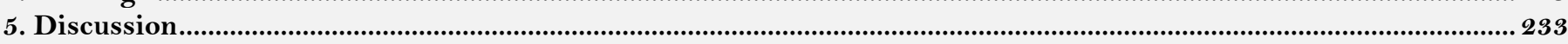

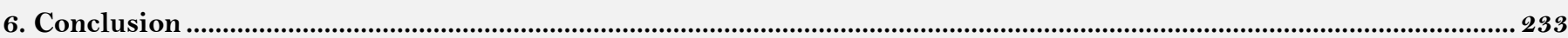

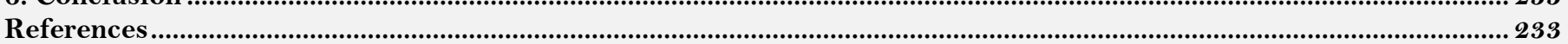




\section{Contribution of this paper to the literature}

This study contributes to existing literature by evaluating the impact of the provision of long-term credit

(LTC) on the growth of small and young firms in developing countries.

\section{Background of the Study}

In developing countries, the main focus is long-term credit (LTC) and the growth of an organization (Leroy, Baumung, Boettcher, Scherf, \& Hoffmann, 2016). For this purpose, different strategies and policies have been developed by different organizations in developing countries to make it possible to increase productivity and economic growth. Developing countries focus on the achievement of LTC without focusing on the subsequent effects on the environment and other factors (Susilowati, Fuddin, Pramuja, Anindyntha, \& Primitasari, 2019). Some organizations are able to consume innovative technology and tools by having greater access to long-term loans, which could also result in higher returns (Alam \& Murad, 2020). Badayi, Matemilola, Bany-Ariffin, and Theng (2020). This illustrates the fact that a greater provision of LTC helps to benefit new firms at the country level.

The overall process and phenomenon of LTC and its impacts have been gaining considerable attention from academic experts and other analysts over the past few years (Ansah et al., 2016). Nevertheless, the performance of firms has been noticed by several scholars and analysts in different developing nations and regions, as there are a significant amount of firms and organizations that are performing successfully (Léon, 2020). Andrade, Cahn, Fraisse, and Mésonnier (2019) recommended that, in order to address any gaps or shortcomings in a firm's performance (FP), some contextual factors and variables like LTC and STC, which affect the quality of a firm, need to be identified and evaluated in detail. Research on the impact of the growth of employment (GoE) on FP is limited, so studies needs to be conducted on firms and businesses in different developing regions and countries (Leon, 2019). As of yet, no studies have evaluated the direct impact of GoE on LTC and STC performance; therefore, this research is new and justified in understanding the direct influence of GoE and sales of total sales (STS). With regard to external debt, Figure 1 shows that the ratio of debt was different over different time periods.

\section{Developing Country Average External Debt Payments, 2000 - 2017}

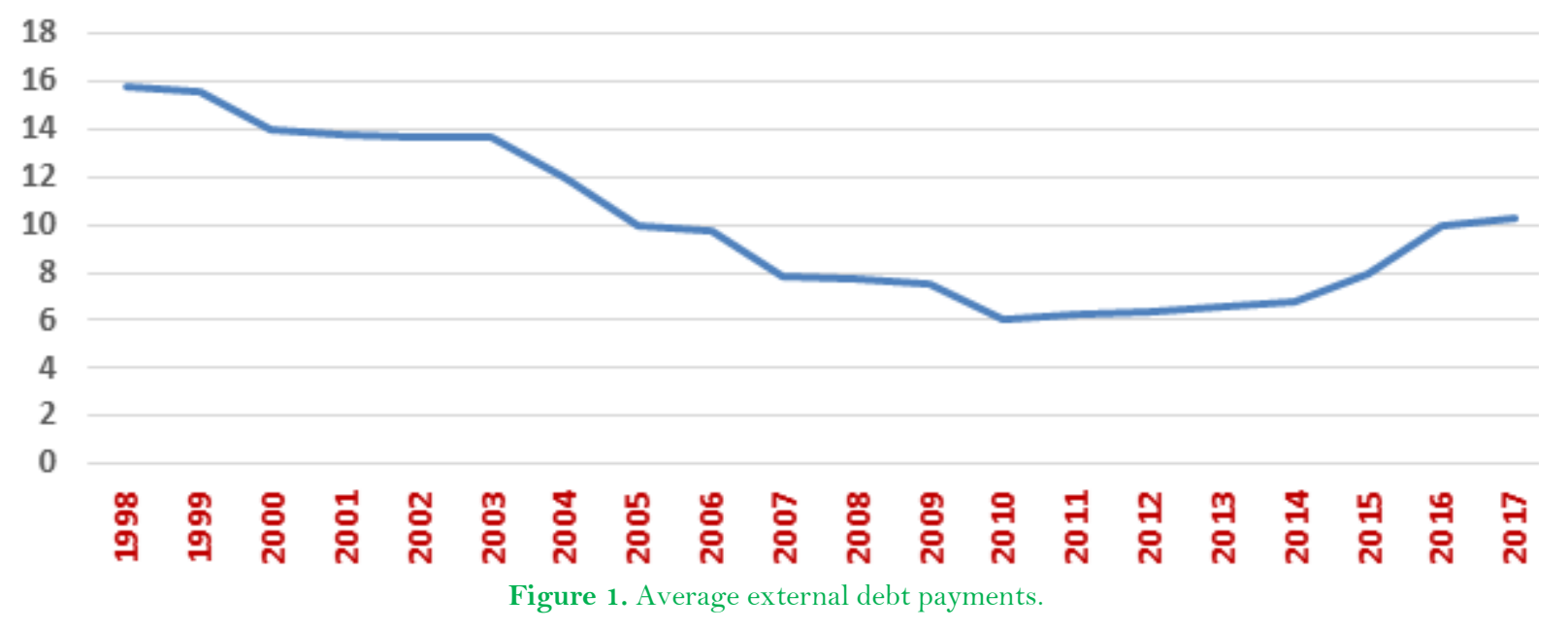

In line with the above justification statement, the aims of the paper are:

- To examine the exclusive impact of GoE on STC and LTC in developing nations.

- To analyze the influence of STS on the STC and LTC in developing countries.

- To explore the impact of GoE and STS on bank credit (BC) in developing countries.

The given study empirically identifies whether or not a higher degree of LTC provision influences the development of small and medium organizations and businesses. Therefore, the given effort has profound theoretical benefits, as well as practical impacts. Theoretically, the results of the given study contribute to the current knowledge on the above variables through an analysis of the effects of GoE on LTC and STC in developing countries. The remainder of the research study is framed as follows: Section two discusses and presents current literature on long-term and short-term finance, as well as the organization's overall performance and presentation; Sections three and four consist of the methodology of the study and the data of the paper; Section five presents the main econometric outcomes and findings, as well as robustness checks; Finally, section six provides a significant demonstration on the types of access to credit and a logical conclusion.

\section{Literature Review}

\subsection{Theory of Long-Term Finance (LTF)}

This theory is mainly studied and developed within the disciplines of management, finance, economics, and accountancy (Schoenmaker \& Schramade, 2019). Theoretically, this theory is concerned with the investment and deployment of assets and liabilities over time, as it is predominantly about performing valuation and asset or money allocation that is based on risk, challenges, and uncertainty over future consequences, while incorporating the time value of money (Schroeder, Clark, \& Cathey, 2019). According to this theory, financing and crediting play a crucial role in the development of every business and firm, mainly because, according to Schoenmaker and Schramade (2019), firms often need financing to pay for assets, equipment, and other significant items for their business. This theory also states that LTC and support are usually needed to acquire new assets and resources for the overall development of the business and firm expansion (Andersen, 2020). Moreover, this theory demonstrates the fact that LTF is expected to have a direct impact on overall business development by stimulating some forms of investment. This leads to an increase in employment in the region. In other words, organizations incorporate LTC 
to buy fixed resources and assets to finance working capital, which leads to an increase in sales and employment (Dou \& Ji, 2019).

\subsection{The Relationship between Employment Growth and Bank Credit}

Sharifi, Haldar, and Rao (2019) describe the fact that the relationship between bank credit and employment growth as complicated because the variables that play a vital role in measuring the access of an organization to finance, which also reflects its petition for labor. Botev, Égert, and Jawadi (2019) have examined the fact that organizations that have access to finance are more likely to experience employment growth than those that do not have access to finance. The research conducted by Aghion, Bergeaud, Cette, Lecat, and Maghin (2019) has stated that the relationship between bank credit and employment growth can be determined with the help of credit bureaus that act as an exogenous shock for the supply of credit. This also leads to employment growth of up to $5 \%$, compared to countries where $\mathrm{CB}$ has not been introduced yet. It has been proved by the theory of LTF that this relationship focuses on the deployment of resources and accountabilities. Therefore, this paper poses the following hypothesis:

H1: There is a direct and significant connection between bank credit and employment growth.

\subsection{The Interdependence between the Growth of Employment and Short-Term Credit}

According to Aghion et al. (2019), an STC is a form of credit that is developed to support short-term personal credit, as well as business and firm capital. According to Cecchetti and Kharroubi (2019), this directly impacts levels of employment. Moreover, Palacín-Sánchez, Canto-Cuevas, and di-Pietro (2019) demonstrate that short-term credit (STC) is a type of credit that mainly includes a borrowed wealth quantity and interest that must be paid by a given period-usually within a year from getting the loan. These factors all directly and significantly impact the GoE in firms and businesses. According to Mian, Sufi, and Verner (2020), STC is a value option and opportunity, especially for small firms or startups in developing countries, which results in a huge amount of employment and firm growth. Moreover, according to the corporate financial institute (CFI), an STC is a form of loan and credit that is entirely generated to support small business capital requirements because STC provides fast cash and capital when the cash flow of a business is deficient (Ferrando \& Mulier, 2013). These types of credits and loans have shorter repayment periods than traditional credit, which is why they are extremely attractive and positive options for employment generation in small firms. According to Li, Loutskina, and Strahan (2019), this directly affects the overall development and performance of the business. The above theory of financing supports the interdependence between STC and GoE and the growth of the firm because the theory of LTF states that credit and financing prove to be significant for the creation of employment in businesses, as they provide quick capital to firms.

H2: There is a significant connection between employment growth and STC.

\subsection{The Nexus between the Development of Employment and Long-term Credit}

LTC and financing can be described as any financial credit tools with a maturity limit of one year, such as bank credits, leasing and bonds, and public and private equity tools. According to Monaghan and Ingold (2019), maturity refers to the amount of time between the conception of a financial claim (bond, financial tools, and loan) and the final payment date and the point at which the remaining interest is due. Extending the capability design of capital is typically seen to be the basis of substantial employment expansion and firm growth because LTC contributes to faster employment growth, significant welfare, and the stability of the business in two favorable ways-by minimizing rollover challenges for borrowers and by improving the availability of LTC tools. This allows employees and businesses to respond life-cycle risks (Aghion et al., 2019). Consequently, the above discussion leads to the establishment of the following hypothesis:

H3: There is a favorable connection between employment growth and LTC.

\subsection{The Association between Sales of Total Sales and Bank Credit}

The performance of a firm is primarily dependent on the positive relationship between the growth of total sales and bank credit. Nurmawati, Rahman, and Baridwan (2020) state that the access of a firm to finance will help it to acquire financial assets and instruments that help it to increase its economic growth Capasso, Gianfrate, and Spinelli (2020). Banks are considered to be the best engine for the increment of the economic growth of a firm. Dai, Byrnes, Liu, and Vasarhelyi (2019) describe the positive impact of bank loans on the development of a business if finance is available and if the added value that has been created by those sectors is available. The LTF theory has supported this relationship by stating that bank credit plays a direct role in the development of a firm, along with the sales of total sales, because finance is required by organizations to pay for equipment and assets. Thus, the present research poses the below hypothesis:

H4: There is a positive interdependence between the sales growth of firms and bank credit.

\subsection{The Interrelation between Sales of a Total of Sales and Short-Term Credit}

STC and finance prove to be very beneficial and advantageous for firms and businesses who need cash flow for further growth and sales; STC can be an invaluable process to get a business through a difficult period until additional resources become available. According to Capasso et al. (2020), the major advantage of STC in terms of sales is that, upon approval, a business can receive benefits within a month, as well as receiving a higher level of total sales and revenue benefits. The amount of STC is optimal for the overall sales of the business, which further impacts the entire economy of the firm. In well-structured markets and businesses, borrowers will enter short-term contracts based on their financial requirements and how they agree to distribute the issues involved at various maturities. This directly influences the sales process and positively impacts the sales of total sales ratio (FuertesCallen \& Cuellar-Fernandez, 2019). What matters for the financial capability of the contracts is that borrowers have complete access to financial tools that allow firms to experience a significant degree of sales and revenue. Therefore, this study proposes the following hypothesis:

H5: There is a positive relationship between the growth of a firm's sales and STC. 


\subsection{The Connection between the Sales of Total Sales and Long-Term Credit}

According to Wang, Wu, Yin, and Zhou (2019) the advantages and benefits offered by LTC compared to STC are mostly related to their different maturities and procedures, as long-term financing offers longer benefits, in terms of financial benefits and sales, at a fixed-rate. As described by Chaudhuri, Voorhees, and Beck (2019), LTC enables businesses and firms to align their capital structures with their long-term strategic objectives, which provides direct benefits in terms of sales and revenue, thereby affording the firm more time to realize a return on investment (RoI). The maturity linked to long-term financing effectively affects sales, as well as improving the revenue generated from total sales. Empirical papers have pointed out that a firm can gain huge sales and revenue benefits from long-term connections with the same investor (Karabarbounis \& Macnamara, 2019). Recent research papers have demonstrated that LTC provides greater flexibility in terms of sales and resources to fund capital demands. Hence, based on the above arguments, this study hypothesizes that:

H6: There is a direct and favorable connection between long-term financing and the sales growth of firms.

\section{Research Methods}

This study used methods introduced by Fafchamps and Schündeln (2013) and applied them to a multiple country framework. This method differentiates from the original strategy in two ways. The method developed by Fafchamps and Schündeln (2013) considers municipalities and, in line with recent work by Léon (2020), this study considers countries. The method followed for calculating growth opportunities is perceived to be a bit different than the original method. A specific measure for each sector-country has been developed. The growth opportunity index has been calculated on the basis of the method followed by Fafchamps and Schündeln (2013), which considers two measures of inculcation for each reference group. Firm size and age have been considered as the characteristics for the reference groups. The basic econometric model is as follows:

$$
g_{i s c t}=\beta\left(G_{s c t} \times F_{c t}\right)+\delta G_{s c t}+\alpha_{s t}+\alpha_{c t}+\varepsilon_{i s c t}
$$

where the subscripts i, s, c and t refer to firm, country, sector and year. The term $g_{\text {isct }}$ represents the annual rate of growth for the firm (i) belonging to sector (s) in country (c) and in the year (t). The term $F_{c t}$ represents the development of the banking sector in each country. The study introduces vectors of sector-year dummies and country year dummies so that the unobserved country and sectoral factors can be controlled. The term $G_{s c t}$ is included in the regression, in order to account for shocks affecting the sectors and countries that are measured by growth opportunities. Equation 1 has been extended to include short- and long-term loans and credit availed by the organizations:

$$
g_{i s c t}=\beta_{S T}\left(G_{s c t} \times F_{c t}^{S T}\right)+\beta_{L T}\left(G_{s c t} \times F_{c t}^{L T}\right)+\delta G_{s c t}+\alpha_{s t}+\alpha_{c t}+\varepsilon_{i s c t}
$$

The term $F_{c t}^{S T}$ represents the ratio of the STC to the GDP of country (c) in time (t), and the term $F_{c t}^{L T}$ represents the ratio of the LTC of a firm to the GDP in a certain country (c) and time ( $\mathrm{t}$ ). The literature supports the supposition that the availability of STC is beneficial for firm growth.

\subsection{Variables}

Firm level data was extracted from the ES database of the World Bank. The firm level data was used to build the dependent variables: employment growth and total sales growth. The data on total sales and the number of employees from the preceding year and a further three years before the surveys were also included. Data regarding sales has also been collected on the same grounds. However, the sales values were deflated using a base year (2010) and the values for each country's GDP deflator was sourced from WDI. The index of growth opportunity was calculated using the average rate of growth of the reference group that comprises less constrained firms. In the basic model, 50 employees were considered. Some sectors in developing economies do not include firms with more than 50 or 100 employees; Therefore, they are both considered to be the benchmark size. Recent research has proven that older firms are more capable of gaining access to bank loans than younger organizations, irrespective of size. Therefore, the reference threshold for a firm's age has been mandated at 25 and 20 years. The growth opportunity in this scenario reflects the growth of the organizations' employment and sales. Dummy variables regarding the sector of the firm, i.e. whether it is a subsidiary, exporter, privately held, or government owned, are also introduced in the study. The independent variables represent the maturity of the bank credits allowed for firms under consideration. Data regarding these variables were collected from the credit structure database. The independent variables in this study are: The total bank credit over GDP as a sum of short- and LTC, STC, defined as the credit extended by the banking sector over GDP to organizations with a maturity period of one year or less, and LTC, defined as the credit extended by the banking sector over GDP with a maturity of over a year. The variable total credit accounts for the total loans extended to organizations by banks.

\subsection{Sample}

The total sample consisted of 52 countries characterized by their size and age. The period under consideration was 2006-2016. The sample consisted of firms from 43 countries, with the final sample representing a total of 19282 firms from countries under consideration. In Table 1, the first column represents the name of the country from which the data was collected; the second column details the year in which the data was collected; the third column represents the total number of firms registered on the database; and the next two columns (size and age) represent the total number of firms characterized according to specifications of age and size. 
Table 1. Sample

\begin{tabular}{|c|c|c|c|c|c|c|}
\hline Country & Year & Obs. & & Benchmark & & \\
\hline & & & Size $>50$ & Size $>100$ & Age $>20$ & Age $>25$ \\
\hline Albania & 2007 & 216 & 19 & 7 & 1 & 1 \\
\hline Albania & 2013 & 227 & 31 & 8 & 6 & 0 \\
\hline Azerbaijan & 2009 & 265 & 56 & 30 & 59 & 55 \\
\hline Azerbaijan & 2013 & 291 & 37 & 16 & 24 & 12 \\
\hline Bahamas & 2010 & 130 & 33 & 17 & 64 & 47 \\
\hline Barbados & 2010 & 132 & 36 & 26 & 52 & 35 \\
\hline Belarus & 2008 & 222 & 75 & 54 & 38 & 35 \\
\hline Belarus & 2013 & 294 & 71 & 47 & 68 & 34 \\
\hline Botswana & 2006 & 242 & 42 & 21 & 40 & 24 \\
\hline Botswana & 2010 & 216 & 48 & 24 & 61 & 41 \\
\hline Bulgaria & 2007 & 942 & 273 & 160 & 42 & 33 \\
\hline Bulgaria & 2009 & 238 & 48 & 30 & 13 & 12 \\
\hline Bulgaria & 2013 & 272 & 60 & 35 & 68 & 11 \\
\hline BurkinaFaso & 2009 & 283 & 39 & 20 & 45 & 34 \\
\hline Burundi & 2006 & 211 & 14 & 3 & 24 & 13 \\
\hline Burundi & 2014 & 131 & 20 & 7 & 34 & 22 \\
\hline Chile & 2004 & 872 & 366 & 239 & 385 & 300 \\
\hline Chile & 2006 & 802 & 278 & 160 & 418 & 318 \\
\hline Chile & 2010 & 913 & 375 & 253 & 569 & 467 \\
\hline Congo & 2009 & 57 & 6 & 3 & 12 & 10 \\
\hline Croatia & 2013 & 303 & 50 & 29 & 92 & 25 \\
\hline Czech Republic & 2009 & 187 & 64 & 38 & 6 & 5 \\
\hline Czech Republic & 2013 & 227 & 47 & 26 & 91 & 4 \\
\hline Co^te d'Ivoire & 2011 & 257 & 32 & 25 & 36 & 18 \\
\hline DR Congo & 2007 & 265 & 17 & 9 & 42 & 36 \\
\hline DR Congo & 2011 & 286 & 45 & 28 & 72 & 41 \\
\hline DR Congo & 2012 & 362 & 38 & 14 & 57 & 34 \\
\hline Djibouti & 2014 & 131 & 4 & 4 & 51 & 34 \\
\hline Dominica & 2011 & 145 & 14 & 5 & 33 & 24 \\
\hline Estonia & 2008 & 221 & 89 & 55 & 19 & 11 \\
\hline Estonia & 2014 & 210 & 34 & 19 & 58 & 3 \\
\hline Fyr Macedonia & 2006 & 283 & 80 & 47 & 45 & 36 \\
\hline Fyr Macedonia & 2012 & 318 & 31 & 15 & 84 & 18 \\
\hline Gabon & 2007 & 91 & 15 & 9 & 24 & 19 \\
\hline Georgia & 2006 & 282 & 54 & 25 & 11 & 9 \\
\hline Georgia & 2011 & 251 & 31 & 12 & 24 & 11 \\
\hline Grenada & 2012 & 121 & 18 & 9 & 61 & 46 \\
\hline Guinea & 2008 & 185 & 8 & 4 & 11 & 8 \\
\hline Guinea Bissau & 2009 & 131 & 6 & 4 & 14 & 7 \\
\hline Hungary & 2006 & 278 & 111 & 74 & 18 & 8 \\
\hline Hungary & 2014 & 240 & 47 & 31 & 57 & 11 \\
\hline Jordan & 2013 & 372 & 103 & 71 & 129 & 87 \\
\hline Kazakhstan & 2010 & 415 & 140 & 93 & 10 & 7 \\
\hline Kazakhstan & 2012 & 485 & 82 & 52 & 42 & 13 \\
\hline Kosovo & 2008 & 226 & 21 & 12 & 30 & 16 \\
\hline Kosovo & 2011 & 156 & 15 & 6 & 47 & 11 \\
\hline Kyrgyz Republic & 2008 & 181 & 42 & 22 & 28 & 32 \\
\hline Kyrgyz Republic & 2012 & 241 & 55 & 25 & 27 & 8 \\
\hline Latvia & 2006 & 210 & 94 & 58 & 7 & 7 \\
\hline Latvia & 2012 & 237 & 34 & 21 & 38 & 4 \\
\hline Lithuania & 2007 & 239 & 71 & 49 & 14 & 11 \\
\hline Lithuania & 2012 & 186 & 45 & 23 & 38 & 8 \\
\hline Madagascar & 2007 & 38 & 17 & 9 & 6 & 5 \\
\hline Madagascar & 2007 & 380 & 98 & 51 & 126 & 88 \\
\hline Madagascar & 2014 & 278 & 62 & 45 & 63 & 42 \\
\hline Malaysia & 2016 & 537 & 223 & 123 & 169 & 92 \\
\hline Mali & 2008 & 421 & 12 & 7 & 46 & 26 \\
\hline Mali & 2011 & 216 & 14 & 2 & 24 & 14 \\
\hline Mali & 2015 & 104 & 32 & 10 & 35 & 25 \\
\hline Morocco & 2014 & 282 & 92 & 52 & 112 & 88 \\
\hline Nigeria & 2007 & 95 & 13 & 2 & 24 & 22 \\
\hline Nigeria & 2013 & 1,257 & 95 & 43 & 313 & 185 \\
\hline Poland & 2007 & 248 & 73 & 45 & 53 & 32 \\
\hline Poland & 2012 & 384 & 82 & 46 & 158 & 51 \\
\hline Romania & 2008 & 362 & 127 & 83 & 12 & 12 \\
\hline Romania & 2012 & 466 & 97 & 52 & 105 & 11 \\
\hline Russia & 2008 & 783 & 383 & 264 & 116 & 102 \\
\hline Russia & 2011 & 3,167 & 628 & 324 & 253 & 115 \\
\hline Rwanda & 2007 & 141 & 13 & 8 & 29 & 18 \\
\hline Rwanda & 2012 & 183 & 37 & 17 & 30 & 32 \\
\hline Senegal & 2002 & 36 & 15 & 9 & 10 & 7 \\
\hline Senegal & 2008 & 400 & 28 & 11 & 69 & 52 \\
\hline Senegal & 2013 & 410 & 52 & 27 & 102 & 65 \\
\hline Serbia & 2008 & 318 & 98 & 70 & 80 & 75 \\
\hline Serbia & 2012 & 287 & 65 & 42 & 104 & 28 \\
\hline Ukraine & 2009 & 661 & 189 & 133 & 90 & 81 \\
\hline Ukraine & 2012 & 670 & 130 & 78 & 77 & 23 \\
\hline Yemen & 2011 & 312 & 57 & 33 & 93 & 71 \\
\hline Yemen & 2012 & 272 & 44 & 27 & 122 & 72 \\
\hline
\end{tabular}




\section{Findings}

The descriptive statistics have been reported in Table 1. It can be seen that the mean employment growth is 4.4 , whereas the sales growth is 0.8 percent. Moreover, the descriptive analysis showed that most firms wer 15 years old and the average number of employees appointed was eleven. Moreover, 17 percent of these firms belong to the export sector, 14 percent operate as subsidiaries, 5.6 percent operate as private organizations and 0.39 percent are owned by the government. The average amount of total credit extended to organizations is 37 percent; of this percentage, 12 percent has been characterized as a short-term loan and 25 percent has been considered to be a long-term loan.

Table 2. Descriptive statistics

\begin{tabular}{|c|c|c|c|c|}
\hline Variable & Mean & Std. Dev & Min & Max \\
\hline \multicolumn{5}{|l|}{ Dependent Variable } \\
\hline Growth of employment & 4.4207 & 11.359 & -31.951 & 47.144 \\
\hline Growth of total sales & 0.8468 & 20 & -53.594 & 65.369 \\
\hline \multicolumn{5}{|l|}{ Independent variables } \\
\hline $\mathrm{F}$ (total credit over GDP) & 36.813 & 27.501 & 0.7265 & 122.57 \\
\hline $\mathrm{F}^{s T}(\mathrm{STC}$ over GDP $)$ & 11.842 & 8.64 & 0.703 & 51.764 \\
\hline $\mathrm{F}^{L T}($ over GDP $)$ & 25.342 & 23.051 & 0.027 & 92.049 \\
\hline \multicolumn{5}{|l|}{ Control variables } \\
\hline Size (in log) & 2.4109 & 0.7935 & $\mathrm{O}$ & 3.8919 \\
\hline Age & 15.189 & 11.147 & 0 & 100 \\
\hline Export & 0.1759 & 0.3805 & $\mathrm{O}$ & 1 \\
\hline Subsidiary & 0.1443 & 0.3511 & $\mathrm{O}$ & 1 \\
\hline State-owned & 0.0039 & 0.0612 & 0 & 1 \\
\hline Privately-held & 0.5624 & 0.496 & 0 & 1 \\
\hline
\end{tabular}

Table 2 summarizes the credit representation of the total sample, i.e. the 52 developing countries that have been taken into consideration. The basic descriptive statistics displayed in Table 2 show that the total credit represents 47 percent of the GDP of the developing countries, and about 60 percent of the loans have credit maturities that are greater than one year; In other words, it is predominantly long-term loans that have been issued. It can be seen from the trends presented in the table that the level of LTC increases with the relative level of income. For example, we can see that, in low income countries, long-term bank loans represent less than 5 percent of the total loans, although they exceed 50 percent in high-income countries.

\begin{tabular}{|c|c|c|c|c|c|c|}
\hline \multicolumn{7}{|c|}{ Credit over GDP } \\
\hline Total & & Short-t. & Long-t. & Long-t. ${ }^{a}$ & Obs & Country \\
\hline All countries & 46.8 & 13.7 & 33.7 & 59 & 1,200 & 52 \\
\hline By income level Low income & 11.5 & 7.1 & 4.4 & 33.7 & 194 & 10 \\
\hline Lower middle income & 21.7 & 9.5 & 12.2 & 48.0 & 168 & 10 \\
\hline Upper middle income & 42.7 & 11.8 & 30.9 & 65.3 & 297 & 12 \\
\hline High income & 70.4 & 19.2 & 51.2 & 70.1 & 541 & 20 \\
\hline
\end{tabular}

\subsection{Total Credit}

First, the effects of the total credit on employment growth have been analyzed and are presented in Table 3. The coefficient of interest is the interaction term $\mathrm{G}^{*} \mathrm{~F}$. The positive coefficients imply that small firms are growing more successfully, especially if they are positioned in a country with a high level of credit. The results also point out that total credit doesn't necessarily stimulate employment growth in small firms. The computed coefficients of interaction terms are positive, yet insignificant. The young firms (the results are shown in columns 6-10) provide more positive conclusions, indicating that the impact of total credit on employment growth is significant at the 10 and 5 percent level of significance. The firm level control variables are reliable and consistent with expectations. 


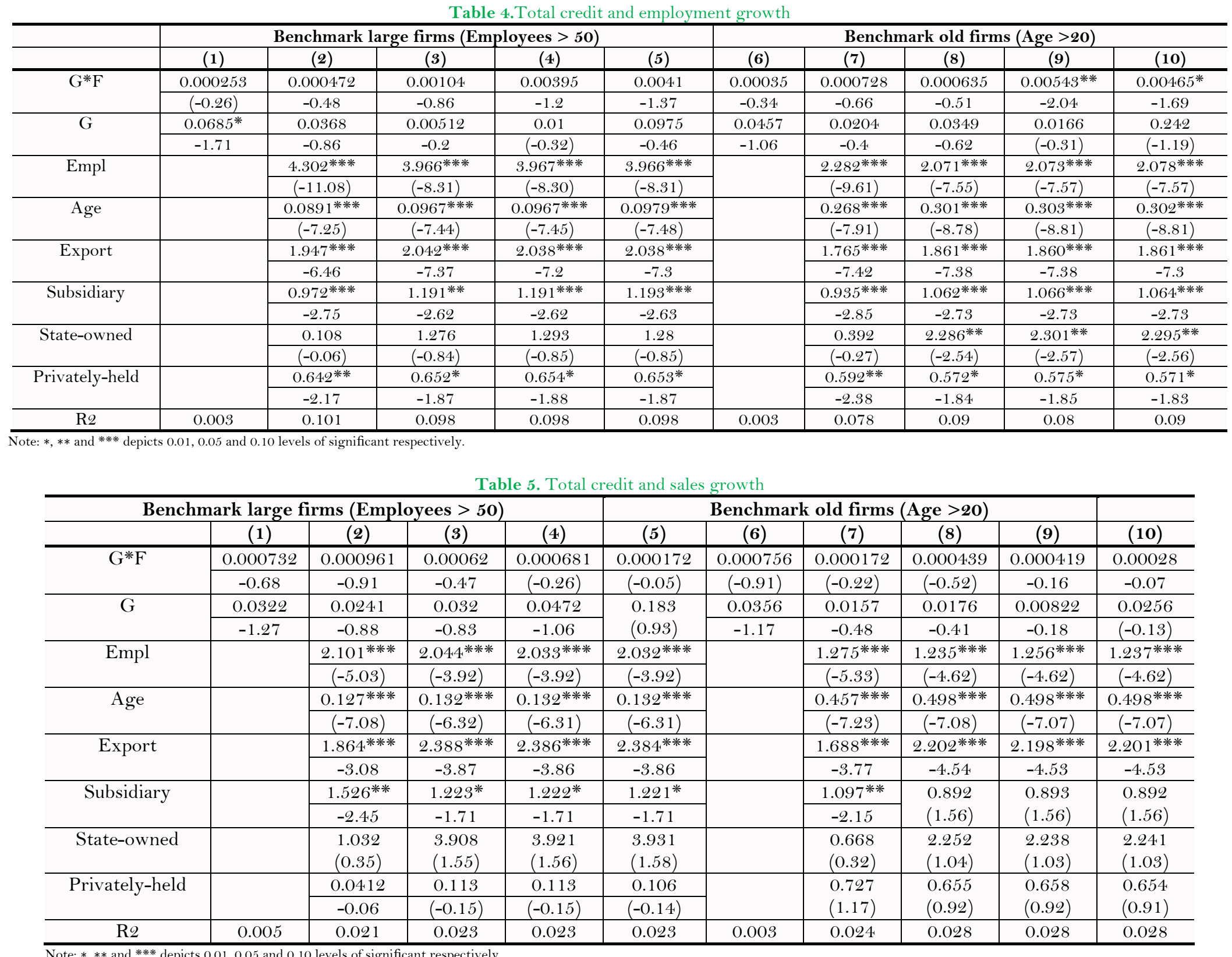




\begin{tabular}{|c|c|c|c|c|c|c|c|c|c|c|}
\hline \multicolumn{5}{|c|}{ Benchmark large firms (Employees > 50) } & \multicolumn{5}{|c|}{ Benchmark old firms (Age $>20)$} & \multirow[b]{2}{*}{ (10) } \\
\hline & $(1)$ & $(2)$ & (3) & (4) & (5) & $(6)$ & $(7)$ & $(8)$ & (9) & \\
\hline \multirow[t]{2}{*}{$\mathrm{G}^{*} \mathrm{~F}^{\mathrm{ST}}$} & $0.00635^{*}$ & $0.00603+$ & $0.0102^{* * *}$ & $0.0105^{* *}$ & $0.0104 * *$ & 0.00341 & 0.00186 & 0.00686 & $0.00972^{* * *}$ & $0.0109 * *$ \\
\hline & -1.74 & -1.52 & -2.28 & -2.36 & -2.32 & -0.67 & -0.38 & -1.32 & -2.22 & -2.36 \\
\hline \multirow[t]{2}{*}{$\mathrm{G}^{*} \mathrm{~F}^{\mathrm{LT}}$} & $0.00158^{*}$ & 0.000643 & 0.00032 & 0.00102 & 0.0012 & 0.000189 & 0.000582 & 0.000216 & $0.00482+$ & 0.00287 \\
\hline & $(-1.78)$ & $(-0.58)$ & $(-0.25)$ & -0.32 & -0.32 & $(-0.13)$ & -0.3 & $(-0.13)$ & -1.48 & -0.79 \\
\hline \multirow[t]{2}{*}{ G } & 0.0332 & 0.00688 & 0.0513 & 0.0562 & 0.0348 & 0.0282 & 0.0126 & 0.00473 & 0.043 & $0.377+$ \\
\hline & -0.72 & -0.13 & $(-0.83)$ & $(-0.91)$ & $(-0.14)$ & -0.52 & -0.25 & $(-0.07)$ & $(-0.76)$ & $(-1.58)$ \\
\hline \multirow[t]{2}{*}{ Empl } & & 4.312 **** & $3.967^{* * * * *}$ & $3.967 * * * *$ & 3.967 **** & & $2.282 * * *$ & $2.072^{* * * * *}$ & $2.073^{* * * *}$ & $2.074 * * * *$ \\
\hline & & $(-11.06)$ & $(-8.32)$ & $(-8.32)$ & $(-8.32)$ & & $(-9.61)$ & $(-7.54)$ & $(-7.58)$ & $(-7.59)$ \\
\hline \multirow[t]{2}{*}{ Age } & & $0.0888^{* * * *}$ & $0.0969 * * * *$ & $0.0968^{* * * *}$ & $0.0966^{* * * *}$ & & $0.268^{* * * *}$ & $0.301 * * *$ & $0.302 * * *$ & $0.302 * * * *$ \\
\hline & & $(-7.23)$ & $(-7.43)$ & $(-7.43)$ & $(-7.43)$ & & $(-7.91)$ & $(-8.78)$ & $(-8.81)$ & $(-8.82)$ \\
\hline \multirow[t]{2}{*}{ Export } & & $1.948 * * *$ & $2.042 * * *$ & $2.041 * * *$ & $2.042 * * *$ & & $1.766 * * *$ & $1.861 * * *$ & $1.862^{* * * *}$ & $1.863^{* * * *}$ \\
\hline & & -6.48 & -7.42 & -7.41 & -7.41 & & -7.42 & -7.38 & -7.42 & -7.42 \\
\hline \multirow[t]{2}{*}{ Subsidiary } & & $0.971 * * *$ & $1.198 * * *$ & $1.199 * * *$ & $1.197 * * *$ & & $0.935 * * *$ & $1.062 * * *$ & $1.065 * * *$ & $1.064 * * * *$ \\
\hline & & -2.74 & -2.64 & -2.64 & -2.64 & & -2.87 & -2.73 & -2.73 & -2.73 \\
\hline \multirow[t]{2}{*}{ State-owned } & & 0.0874 & 1.236 & 1.246 & 1.246 & & 0.392 & $2.282^{* * *}$ & $2.293 * *$ & $2.286^{* * *}$ \\
\hline & & $(-0.07)$ & $(-0.82)$ & $(-0.82)$ & $(-0.82)$ & & $(-0.28)$ & $(-2.57)$ & $(-2.56)$ & $(-2.55)$ \\
\hline \multirow[t]{2}{*}{ Privately-held } & & 0.645 *** & $0.655^{*}$ & $0.658^{*}$ & $0.658 *$ & & $0.594 * *$ & $0.589^{*}$ & $0.586^{*}$ & $0.581 *$ \\
\hline & & -2.17 & -1.99 & -1.88 & -1.88 & & -2.32 & -1.87 & -1.89 & -1.87 \\
\hline $\mathrm{R} 2$ & 0.003 & 0.101 & 0.2 & 0.2 & 0.2 & 0.003 & 0.077 & 0.07 & 0.06 & 0.07 \\
\hline
\end{tabular}


able 7. Short- and lon

\begin{tabular}{|c|c|c|c|c|c|c|c|c|c|c|}
\hline \multicolumn{5}{|c|}{ Benchmark large firms (Employees > 50) } & \multicolumn{5}{|c|}{ Benchmark old firms (Age $>20)$} & \multirow[b]{2}{*}{ (10) } \\
\hline & (1) & $(2)$ & $(3)$ & $(4)$ & (5) & (6) & $(7)$ & $(8)$ & (9) & \\
\hline \multirow[t]{2}{*}{$\mathrm{G}^{*} \mathrm{~F}^{\mathrm{ST}}$} & $0.00583+$ & $0.00692 *$ & $0.00842+$ & $0.00867+$ & $0.00941+$ & $0.00815 *$ & $0.0101 * *$ & $0.00918^{* *}$ & $0.00888^{*}$ & $0.00854^{*}$ \\
\hline & -1.61 & -1.92 & -1.48 & -1.5 & -1.57 & -1.93 & -2.43 & -2.05 & -1.88 & -1.82 \\
\hline \multirow[t]{2}{*}{$\mathrm{G}^{*} \mathrm{~F}^{\mathrm{LT}}$} & 0.000557 & 0.000537 & 0.000728 & $0.00544 *$ & $0.00632+$ & $0.00148 * *$ & $0.00101 *$ & 0.000942 & 0.00227 & 0.00323 \\
\hline & $(-0.38)$ & $(-0.36)$ & $(-0.46)$ & $(-1.77)$ & $(-1.62)$ & $(-2.45)$ & $(-1.78)$ & $(-1.33)$ & $(-1.12)$ & $(-1.26)$ \\
\hline \multirow[t]{2}{*}{ G } & 0.00458 & 0.00785 & 0.023 & 0.00442 & 0.0966 & 0.0187 & 0.0454 & 0.0496 & 0.0422 & 0.172 \\
\hline & -0.15 & $(-0.27)$ & $(-0.46)$ & $(-0.08)$ & $(-0.42)$ & $(-0.52)$ & $(-1.17)$ & $(-0.94)$ & $(-0.77)$ & $(-0.85)$ \\
\hline \multirow[t]{2}{*}{ Empl } & & $2.098 * * *$ & $2.054 * * *$ & $2.048^{* * * *}$ & $2.048 * * *$ & & $1.287 * * *$ & $1.252 * * *$ & $1.248 * * *$ & $1.250^{* * * *}$ \\
\hline & & $(-5.04)$ & $(-3.92)$ & $(-3.91)$ & $(-3.91)$ & & $(-5.34)$ & $(-4.64)$ & $(-4.63)$ & $(-4.63)$ \\
\hline \multirow[t]{2}{*}{ Age } & & 0.127 **** & $0.133 * * *$ & 0.133**** & 0.132 **** & & 0.457 **** & $0.501 * * * *$ & $0.501 * * *$ & $0.501 * * * *$ \\
\hline & & $(-7.08)$ & $(-6.32)$ & $(-6.33)$ & $(-6.32)$ & & $(-7.25)$ & $(-7.11)$ & $(-7.11)$ & $(-7.11)$ \\
\hline \multirow[t]{2}{*}{ Export } & & $1.868 * * *$ & $2.393 * * *$ & $2.388^{* * * *}$ & $2.386 * * *$ & & $1.687^{* * * *}$ & $2.198^{* * * *}$ & $2.198 * * *$ & $2.198^{* * * *}$ \\
\hline & & -3.2 & -3.87 & -3.86 & -3.88 & & -3.78 & -4.52 & -4.52 & -4.52 \\
\hline \multirow[t]{2}{*}{ Subsidiary } & & $1.513^{* * *}$ & $1.217^{*}$ & $1.212^{*}$ & $1.212 *$ & & $1.104 * *$ & 0.908 & 0.901 & 0.907 \\
\hline & & -2.42 & -1.72 & -1.72 & -1.72 & & -2.17 & $(1.61)$ & $(1.61)$ & $(1.61)$ \\
\hline State-owned & & $\begin{array}{l}1.076 \\
(0.36)\end{array}$ & $\begin{array}{l}3.998 \\
(1.58)\end{array}$ & $\begin{array}{l}4.086 \\
(1.63)\end{array}$ & $\begin{array}{l}4.102 \\
(1.63)\end{array}$ & & $\begin{array}{l}0.606 \\
(0.27)\end{array}$ & $\begin{array}{l}2.202 \\
(1.02)\end{array}$ & $\begin{array}{l}2.217 \\
(1.02)\end{array}$ & $\begin{array}{l}2.226 \\
(1.02)\end{array}$ \\
\hline \multirow[t]{2}{*}{ Privately-held } & & 0.0441 & 0.106 & 0.102 & 0.104 & & 0.757 & 0.694 & 0.695 & 0.691 \\
\hline & & -0.07 & $(-0.15)$ & $(-0.14)$ & $(-0.15)$ & & $(1.21)$ & $(0.96)$ & $(0.97)$ & (0.96) \\
\hline $\mathrm{R} 2$ & 0.004 & 0.021 & 0.023 & 0.023 & 0.023 & 0.001 & 0.022 & 0.026 & 0.026 & 0.026 \\
\hline
\end{tabular}


Table 4 represents the evaluation of the impact of total credit on total sales growth. The growth opportunity, i.e. the level of the sales growth, is evaluated by calculating the average growth rate of the total sales of large firms (firms with more than 50 employees) and old firms (firms that are older than 20 years). The interaction term $\mathrm{F}^{*} \mathrm{G}$, i.e. the evaluation of the sales growth and total credit, were positive; however, the coefficients weren't significant. The firm level control variables are reliable and consistent with expectations. Small and young firms were observed to have grown significantly faster than their counterparts. Firms belonging to the export sector and subsidiaries presented consistent growth rates that were significant at the 10 and 5 percent levels.

\subsection{Effects of Short-Term and Long-Term Credit}

Table 5 represents the impact of the availability of short-term loans on firm growth from the perspective of employees. Long-term loans, however, seem to have no impact. In particular, the coefficients of the interaction term generated by short-term loans and the growth of employment were statistically significant and positive, irrespective of the size of the firm. The effects of STC were also appeared to be economically significant. On the other hand, it can be seen that the impact of LTC and the interaction terms generated between LTC and employment growth values were positive yet insignificant.

Table 6 presents the impact of short- and LTC on the firms' growth of sales. First, it can be seen that shortterm loans benefit the growth of the firm. Second, the results also indicate that the ratio of LTC over GDP isn't significant; it does not seem to have a reasonable impact on the performance of firms. These results imply that STCs are beneficial for the growth optimization of young and small firms.

\section{Discussion}

This study evaluated the impact of the long- and STC on the employment and sales growth opportunities of firms in 52 developing countries. A wide number of studies have analyzed the effects of long- and STC on the overall performance and growth of organizations. A significant proportion of studies, however, found an insignificant link between LTC and firm growth. A reasonable explanation is that LTC isn't crucial for daily operations, as working capital requirements of small and young firms is markedly important (Field, Pande, Papp, \& Rigol, 2013; Getachew, 2016; Lay, 2020; Leon, 2018; Leon, 2019). Studies by Fisman and Love (2007) and Fafchamps and Schündeln (2013) studied the impact of growth opportunities by including it in the base model and analyzing its relationship with credit growth maturity. These studies also reported the insignificance of LTC extensions and their relevance to firm growth. A study by Léon (2020) focused on the external financial dependence of organizations and credit maturity, and the results indicated that external financial dependence is significant for the STC of firms. This study also pointed out that young firms are significantly correlated with external financial dependence and the provision of STC. A study by Khan, Ghafoor, Qureshi, and Rehman (2018) empirically investigated the role of the banking market, evaluating developments in the financial structure and the growth of financial dependence in the manufacturing sector of china. The study evaluated growth between 19992014. The study employed structural and non-structural methods to evaluate the impact of the banking market structure and its relationship with the growth of the manufacturing sector. The results indicated that competition between banks inspires the growth of the industry. Chauvet and Jacolin (2017) explored the effects of firm performance from the perspective of bank concentration or credit extension activities, and the financial inclusion of firms in emerging and developing countries. This particular study employed the use of firm level data from 79 developing and emerging countries. The results indicated that the distribution of financial services across firms seems to have a positive impact on the overall growth of organizations. This positive impact or growth becomes greater when the bank's concentration is less significant.

\section{Conclusion}

This study evaluated the impact of the provision of long- and STC on the growth of the firms. The study was performed on a dataset of 52 developing countries with a total of 19282 firms characterized on the basis of size (number of employees) and age. The growth of the firms was evaluated on the basis of employment growth and sales. It appears that entrepreneurs in developing economies should be able to benefit from the provision of LTC so that investments can be extended. However, this study found that LTC doesn't have an impact on the sales and employment growth of small and young firms in developing economies. The results also indicated that the availability of STC is beneficial for the growth of small and young firms. The evaluation of the total bank credit pointed out that growth in sales and employment is significant over shorter periods of time because of capital requirements.

The results of this study can be applied when developing policies. The results have indicated that access and availability of STC is of considerable importance for the growth of small firms. Therefore, policies that are developed in favor of LTC may have a negative impact on the growth of new firms. As a result, banking policies in developing economies need to be adjusted so that the client base can be widened, and loans can be extended to parties other than existing clientele. One limitation of this study is the fact that it explores LTC and how it isn't beneficial for the growth of small firms, but it doesn't explore the rationale behind this occurrence. Moreover, the data set was only 52 developing countries, so future studies should focus on diversifying and increasing the sample size.

\section{References}

Aghion, P., Bergeaud, A., Cette, G., Lecat, R., \& Maghin, H. (2019). Coase lecture-the inverted-U relationship between credit access and productivity growth. Economica, 86(341), 1-31.Available at: https://doi.org/10.1111/ecca.12297.

Alam, M. M., \& Murad, M. W. (2020). The impacts of economic growth, trade openness and technological progress on renewable energy use in organization for economic co-operation and development countries. Renewable Energy, 145, 382-390.Available at: https://doi.org/10.1016/j.renene.2019.06.054.

Andersen, K. N. (2020). Forward value creation and digital government: Solving the cost-benefit paradox? Paper presented at the Paper presented at the Electronic Governance and Open Society: Challenges in Eurasia: 6th International Conference, EGOSE 2019, St. Petersburg, Russia, November 13-14, 2019, Proceedings. 
Andrade, P., Cahn, C., Fraisse, H., \& Mésonnier, J.-S. (2019). Can the provision of long-term liquidity help to avoid a credit crunch? Evidence from the Eurosystem's LTRO. Journal of the European Economic Association, 17(4), 1070-1106.Available at: https://doi.org/10.1093/jeea/jvyo20.

Ansah, J. P., Matchar, D. B., Malhotra, R., Love, S. R., Liu, C., \& Do, Y. (2016). Projecting the effects of long-term care policy on the labor market participation of primary informal family caregivers of elderly with disability: insights from a dynamic simulation model. BMC Geriatrics, 1(16), 1-14.Available at: https://doi.org/10.1186/s 12877-016-0243-0.

Badayi, S., Matemilola, B., Bany-Ariffin, A., \& Theng, L. W. (2020). Impact of long-term debt maturity and corporate social responsibility on default probability in developing countries.

Botev, J., Égert, B., \& Jawadi, F. (2019). The nonlinear relationship between economic growth and financial development: Evidence from developing, emerging and advanced economies. International Economics, 160, 3-13.Available at: https://doi.org/10.1016/j.inteco.2019.06.004.

Capasso, G., Gianfrate, G., \& Spinelli, M. (2020). Climate change and credit risk. Journal of Cleaner Production, 266, 121634. Available at: https://doi.org/10.1016/j.jclepro.2020.121634.

Cecchetti, S. G., \& Kharroubi, E. (2019). Why does credit growth crowd out real economic growth? The Manchester School, 87(S1), 128.Available at: https://doi.org/10.1111/manc.12295.

Chaudhuri, M., Voorhees, C. M., \& Beck, J. M. (2019). The effects of loyalty program introduction and design on short-and long-term sales and gross profits. Journal of the Academy of Marketing Science, 47(4), 640-658.Available at: https://doi.org/10.1007/s11747-01900652-y.

Chauvet, L., \& Jacolin, L. (2017). Financial inclusion, bank concentration, and firm performance. World Development, 97, 1-13.Available at: https://doi.org/10.1016/j.worlddev.2017.03.018.

Dai, J., Byrnes, P., Liu, Q., \& Vasarhelyi, M. (2019). Audit analytics: A field study of credit card after-sale service problem detection at a major bank. Rutgers Studies in Accounting Analytics: Audit Analytics in the Financial Industry (Rutgers Studies in Accounting Analytics) (pp. 17-33). Emerald Publishing Limited.

Dou, W., \& Ji, Y. (2019). External financing and customer capital: A financial theory of markups. Retrieved from https://papers.ssrn.com/sol3/papers.cfm?abstract_id=2574953.

Fafchamps, M., \& Schündeln, M. (2013). Local financial development and firm performance: Evidence from Morocco. Journal of Development Economics, 103, 15-28.Available at: https://doi.org/10.1016/j.jdeveco.2013.01.010.

Ferrando, A., \& Mulier, K. (2013). Do firms use the trade credit channel to manage growth? Journal of Banking E Finance, 37(8), 30353046.Available at: https://doi.org/10.1016/j.jbankfin.2013.02.013.

Field, E., Pande, R., Papp, J., \& Rigol, N. (2013). Does the classic microfinance model discourage entrepreneurship among the poor? Experimental evidence from India. American Economic Review, 103(6), 2196-2226.Available at: https://doi.org/10.1257/aer.103.6.2196.

Fisman, R., \& Love, I. (2007). Financial dependence and growth revisited. Journal of the European Economic Association, 5(2-3), 470479.Available at: https://doi.org/10.1162/jeea.2007.5.2-3.470.

Fuertes-Callen, Y., \& Cuellar-Fernandez, B. (2019). Inter-relationship between firm growth and profitability in a context of economic crisis. Journal of Business Economics and Management, 20(1), 86-106.Available at: https://doi.org/10.3846/jbem.2019.6928.

Getachew, Y. Y. (2016). Credit constraints, growth and inequality dynamics. Economic Modelling, 54, 364-376.Available at: https://doi.org/10.1016/j.econmod.2016.01.005.

Karabarbounis, M., \& Macnamara, P. (2019). Misallocation and credit market constraints: The role of long-term financing.

Khan, H. H., Ghafoor, A., Qureshi, F., \& Rehman, I. U. (2018). Bank competition, financial development and growth of financially dependent industries: Fresh evidence from China. Global Economic Review, 47(2), 108-134.Available at: https://doi.org/10.1080/1226508x.2018.1436458.

Lay, S. H. (2020). Bank credit and economic growth: Short-run evidence from a dynamic threshold panel model. Economics Letters, 109231.

Leon, F. (2018). The credit structure database.

Léon, F. (2020). The provision of long-term credit and firm growth in developing countries. Economic Modelling, 90, 66-78.Available at: https://doi.org/10.1016/j.econmod.2020.04.023.

Leon, F. (2019). LTF and entrepreneurship. Economic Systems, 43(2), 100690.Available at: https://doi.org/10.1016/j.ecosys.2018.10.004.

Leroy, G., Baumung, R., Boettcher, P., Scherf, B., \& Hoffmann, I. (2016). Sustainability of crossbreeding in developing countries; definitely not like crossing a meadow. Animal, 1O(2), 262-273.Available at: https://doi.org/10.1017/s175173111500213x.

Li, L., Loutskina, E., \& Strahan, P. E. (2019). Deposit market power, funding stability and long-term credit: National Bureau of Economic Research, Inc.

Mian, A., Sufi, A., \& Verner, E. (2020). How does credit supply expansion affect the real economy? The productive capacity and household demand channels. The Journal of Finance, 75(2), 949-994.Available at: https://doi.org/10.1111/jofi.12869.

Monaghan, M., \& Ingold, J. (2019). Policy practitioners' accounts of evidence-based policy making: The case of universal credit. Journal of Social Policy, 48(2), 351-368.Available at: https://doi.org/10.1017/s004727941800051x.

Nurmawati, B. A., Rahman, A. F., \& Baridwan, Z. Z. (2020). The moderating role of intellectual capital on the relationship between non profit sharing financing, profit sharing financing and credit risk to financial performance of islamic bank. The journal Review of Accounting and Finance, $10(1)$, 38-52.Available at: https://doi.org/10.22219/jrak.v10i1.10628.

Palacín-Sánchez, M.-J., Canto-Cuevas, F.-J., \& di-Pietro, F. (2019). Trade credit versus bank credit: A simultaneous analysis in European SMEs. Small Business Economics, 53(4), 1079-1096.Available at: https://doi.org/10.1007/s1 1187-018-0101-x.

Schoenmaker, D., \& Schramade, W. (2019). Investing for long-term value creation. Journal of Sustainable Finance E Investment, 9(4), 356377.Available at: https://doi.org/10.1080/20430795.2019.1625012.

Schroeder, R. G., Clark, M. W., \& Cathey, J. M. (2019). Financial accounting theory and analysis: Text and cases: John Wiley \& Sons.

Sharifi, S., Haldar, A., \& Rao, S. N. (2019). The relationship between credit risk management and non-performing assets of commercial banks in India. Managerial Finance, 45(3), 399-412. Available at: https://doi.org/10.1108/MF-06-2018-0259.

Susilowati, D., Fuddin, M. K., Pramuja, R. A., Anindyntha, F. A., \& Primitasari, N. (2019). Analysis of Effect of foreign direct investment, debt to the IMF and stock values against economic growth in developing countries members of the organization of islamic cooperation (OIC). KnE Social Sciences, 1188-1199.

Wang, X., Wu, W., Yin, C., \& Zhou, S. (2019). Trade credit, ownership and informal financing in China. Pacific-Basin Finance Journal, 57, 101177.Available at: https://doi.org/10.1016/j.pacfin.2019.101177. 